\title{
Romatoid Artritli Kadın Hastalarda Üst Ekstremitede Hangi Kasların Güçleri Hastalık Aktivitesi, Fonksiyonellik ve Engellilik ile İlişkilidir?*
}

\author{
Ozan Volkan YURDAKUL, Okan KÜÇÜKAKKAŞ
}

Bezmialem Vakıf Üniversitesi Tıp Fakültesi, Fiziksel Tıp ve Rehabilitasyon Anabilim Dalı, İstanbul.

\section{ÖZET}

$\mathrm{Bu}$ çalışmada kas gücü kaybına neden olan romatoid artrit (RA) hastalarında; dominant üst ekstremitede hangi kas gruplarının etkilendiğinin, bu etkilenmelerin hastalık aktivitesi, fonksiyonellik ve engellilik ile ilişkisinin araștııılması amaçlanmıștır. Calışmaya 30 RA hastası, 30 sağlıklı gönüllü dahil edildi. Hasta grubunda "hastalık aktivite skoru-28 (DAS28)", "üst ekstremite fonksiyonel indeksi-15 (UEFI-15)" ve "sağllk değerlendirme anketi (HAQ)" skorları hesaplandı. Gönüllülerin dominant üst ekstremitelerinden; başparmak interfalanjiyal (IP) ve metakarpofalanjiyal (MKF), diğer parmakların proksimal interfalanjiyal (PIP) ve MKF eklem fleksörlerinden, el bileği ile dirsek fleksör ve ekstansörleri ile omuzun fleksör, ekstansör, iç rotator (IR), dış rotator (ER), abduktör ve addüktör kaslarının maksimum ve ortalama kas güçleri ölçüldü. Hastaların toplam PIP ve MKF (PIP toplam, $\mathrm{MKF}_{\text {toplam}}$ ) değerleri elde edildi. Hasta ve kontrol grubu arasında yas ve boy açısından anlamlı fark görülmemiştir. Kas güçleri açısından; RA grubunda, başparmak IP ve MKF ile $\mathrm{PIP}_{\text {toplam, }} \mathrm{MKF}_{\text {toplam }}$ ve el bileği fleksiyonunun maksimum ve ortalama değerleri, kontrol grubundan anlamlı düşük tespit edilirken; omuz ekstansiyonu ortalama ve adduksiyon, abduksiyon maksimum ve ortalama kas güçleri RA grubunda düşük tespit edilmiştir. DAS28 ile parmak fleksörleri, el bilek ekstansörleri ve diş rotatorlar haricindeki omuz kasları negatif ilişkiliyken; UEFI-15 skorları ile bilek ekstansör ve omuz kuşağı kasları pozitif ilişkili bulunmuştur. HAQ skorlarının ortalama el bilek fleksiyonu, dirsek ekstansiyonu ve omuz kuşak kasları ile ilișkili olduğu saptanmıștır. El ve el bileği kasları hastalık aktivitesinden en çok etkilenenler olmalarına rağmen dirsek ve omuz kuşağı kaslarının fonksiyonelliği ve engelliliği daha çok etkilediği görülmüştür. Üst ekstremite kaslarının toplam kuvveti, hastalık aktivitesi; fonksiyonellik ve engellilik ile ilişkili bulunmuştur.

Anahtar Kelimeler: Romatoid artrit. Kas gücü. DAS28. UEFI-15. HAQ.

Which Muscles' Strength in Upper Extremity are Related to Disease Activity, Functionality, and Disability in Female Patients with Rheumatoid Arthritis?

\begin{abstract}
The aim of this study is to investigate which muscle groups are affected in dominant upper extremity, and relation of these effects with disease activity, functionality, disability in patients with rheumatoid arthritis (RA) which causes muscle strength loss. 30 RA patients, 30 healthy volunteers were included in this study. In patient group, "disease activity score-28 (DAS28)", "upper extremity functional index-15 (UEFI-15)", "health assessment questionnaire (HAQ)" scores were calculated. From dominant upper extremities of volunteers; maximum and average muscle strengths of thumb interphalangeal (IP), metacarpophalangeal (MCP), proximalinterphalangeal (PIP) and MCP joint flexors of other fingers, wrist and elbow flexors/extensors, flexor, extensor, internal rotator (IR), external rotator (ER), abductor/adductor muscles of shoulder were measured. Total PIP/MCP ( PIP $\left._{\text {total }}, \mathrm{MCP}_{\text {total }}\right)$ values of patients were obtained. There was no significant difference between patient and control groups in age/height. In muscle strengths; thumb IP, $\mathrm{MCP} / \mathrm{PIP}_{\text {total }}, \mathrm{MCP}_{\text {total }}$, wrist flexion mean and maximum values were significantly lower in RA group than control group; mean shoulder extension, maximum adduction/abduction, mean muscle strengths were low in RA group. DAS28, finger flexors, wrist extensors, shoulder muscles except ER were negatively related; UEFI-15 scores, wrist extensor, shoulder girdle muscles were positively related. HAQ scores were associated with mean wrist flexion, elbow extension, shoulder girdle muscles. Although hand and wrist muscles are the most affected by disease activity, it has been observed that elbow and shoulder girdle muscles affect functionality and disability more. Total strength of upper extremity muscles has been associated with disease activity, functionality and disability.
\end{abstract}

Key Words: Rheumatoid arthritis. Muscle strenght. DAS28. UEFI-15. HAQ.

Geliş Tarihi: 09 Şubat 2019

Kabul Tarihi: 08 Nisan 2019

* "16. TIHUD International Internal Medicine Training Meetings" kongresinde sözel bildiri olarak sunulmuştur (22 - 24 Şubat 2019, Bükreş/ Romanya)

Dr. Ozan Volkan YURDAKUL

Bezmialem Vakıf Üniversitesi Tıp Fakültesi, Fiziksel Tıp ve Rehabilitasyon Anabilim Dal Adnan Menderes Blv. 34093 Fatih / İstanbul Tel.: 05543725127

E-posta: yurdakul_ozan@yahoo.com
Romatoid artrit (RA) otoimmünite kaynaklı eklem sinovyumunun etkilendiği, kronik, inflamatuar bir hastalıktır'. Prevalansı Orta Avrupa'da ortalama \%0,5 olarak tespit edilmiştir ${ }^{2}$. Hastalık süresinin ve hastalık aktivitesinin artması ile sadece eklemler değil, eklem çevresindeki kaslar, bağlar ve tendon kılıfları da etkilenmektedir ${ }^{1}$. RA her ne kadar eklem inflamasyonu ile karakterize bir hastalık olarak tanımlansa da vücut kompozisyonunda da değişiklik yapmaktadır. RA 


\section{O.V. Yurdakul, ark.}

hastalarında tedrici kas gücü kaybı aynı yaştaki genel popülasyona göre daha fazla görünmektedir hatta çoğu zaman yaşlı popülasyon ile kıyaslanabilecek düzeyde$\operatorname{dir}^{3}$. RA hastalarında normal veya artmış vücut ağırlığıla birlikte kas kitlesinde kayıp ve aynı zamanda kas içi yağ kitlesinde artışla seyreden "romatoid kaşeksi" adlı fenomen hastalığın iyi bilinen özelliklerinden birisidir ${ }^{4}$. Bu duruma RA patogenezinde önemli rol oynayan tümör nekroz faktör (TNF)- $\alpha$ ve diğer bazı sitokinlerin kas üzerindeki katabolik etkileri neden olmaktadır ${ }^{5}$. Kas kitlesindeki kayıp, bu hasta grubunda kas gücündeki kayıpla ilişkili olup aynı zamanda RA, yaşla ilişkili sarkopenide de artışa neden olmaktadır ${ }^{6,7}$.

Romatoid artritin vücut fonksiyonları üzerine etkisi günlük yaşam aktivitelerinde kısıtlanma şeklinde ortaya çıkmaktadır. Bu kısıtlanma ağrı, eklem hareket açıklığı (ROM) kısıtlanması, kas güçsüzlüğü ve aerobik kapasitede azalmanın birleşimi şeklinde gelişir ${ }^{8}$. $\mathrm{Bu}$ parametrelerden kas gücündeki azalma RA'nın daha ilk dönemlerinde tezahür etmektedir ${ }^{9}$. Hastalık aktivitesini azaltmak kadar hastalık progresyonunu durdurmak ve fonksiyonelliği korumak hatta bir miktar fonksiyon artışı kazanmak bu hastalar için elzemdir. Bunu sağlayabilmek için pratikte multidisipliner bir yaklaşımla ilaç tedavisi, egzersiz ve fizik tedavinin kombinasyonu olan bir tedavi şekli önerilmektedir ${ }^{10}$.

Günümüzde RA tedavisinde el egzersizleri kullanılmaktadır fakat son 50 yılda el egzersizlerinin bu hasta grubunda zararlı olabileceği düşünülmüştür ${ }^{11}$. Dirençli egzersizler sirasinda yapilan fleksiyon hareketinin mekanik stres aracılığıyla metakarpofalanjiyal (MKF) eklemler üzerine yük bindireceği öne sürülmüştür ${ }^{11}$. $\mathrm{Bu}$ nedenle bu hastalara uzunca bir süre pasif egzersizleri ve germe egzersizlerini içeren kısıtlı bir egzersiz programı uygulanmıştır. Son zamanlarda yapılan çalışmalarda RA hastalarında aktif egzersizlerin hastalık aktivitesini artırmadığ 1 ve eklem harabiyetine yol açmadığı kanıtlanmıştır ${ }^{12,13}$. American Collage of Rheumatology (ACR) kılavuzu eklemlere yönelik güçlendirme, aktif ROM içeren ev programları önermekle birlikte spesifik kas grupları için egzersiz önermemiştir ${ }^{14}$. Hatta güncel kılavuzlarda egzersizle ilgili öneri bulunmamaktadır ${ }^{15}$. Benzer şekilde European League Against Rheumatism (EULAR) de güncel kılavuzlarında erken artritte dinamik egzersizlerin gerekli olduğunu belirtmiş ama hangi kas gruplarının hedef alınacağını belirtmemiştir ${ }^{16}$.

Tedavi programlarının oluşturulması konusunda literatürde bir eksiklik olduğu görülmektedir. Bunun nedeni yapılan çalışmaların el fonksiyonlarındaki etkilenmeyi göz önüne alarak, çoğunlukla el parmakları ve el bileği bölgesiyle ilişkili kasların kas güçlerine yoğunlaşmış olmasıdır. Ayrıca çalışmalarda genellikle el fonksiyonları, tutma ve kavrama tarzında farklı kas gruplarının birlikte çalıştığı hareketlere yoğunlaşılmış olup ayrı ayrı eklemleri hareket ettiren kaslar çalıșılmamıș$\operatorname{tır}^{17-19}$. Bu bağlamda bu çalışmanın amacı kadın RA hastalarının dominant üst ekstremitelerinde hastalık aktivitesi ile etkilenen kas gruplarını tespit etmek, bu kas gruplarının üst ekstremite fonksiyon kaybı ve engellilik ile ilişkisini saptamaktır.

\section{Gereç ve Yöntem}

Kesitsel tasarımlı bu çalışmaya, kliniğimize başvuran 60 gönüllü (30 RA, 30 kontrol) dahil edilmiştir. Çalışma öncesi ilgili kurumun etik kurulundan onay alınmış olup (No: 23/275), çalışmaya katılanların yazılı onamı alınmıştır. Çalışma, World Medical Association Declaration of Helsinki "Ethical Principles for Medical Research Involving Human Subjects”, prensiplerine uygun olarak yapılmıștır. RA hasta grubu için çalışmaya dahil edilme kriterleri: 1) 2010 ACR\&EULAR RA sinıflandırma kriterlerine göre RA tanısı almış olmak 2) 6 aydan uzun semptom süresine sahip olmak 3) Kadın cinsiyet olarak belirlenmiştir. Dişlama kriterleri hem RA hem kontrol grubu için: 1) Onam veremeyecek bilinç düzeyi 2) Ağır komorbiditeler (kanser, ağır kardiyovasküler hastalık ve mental hastalık) 3) Üst ekstremite cerrahi öyküsü 4) Karpal tünel sendromu veya kas gücü defisiti yapacak nöropati şüphesi 5) Kas hastalıkları 6) Kronik tendon fonksiyon bozukluğuna sahip olmak 7) Gebelik olarak belirlenmiştir.

Hasta grubuna, polikliniğe başvuru günü içerisinde fiziyatrist tarafindan eklem muayenesi yapıldı. RA hastalık aktivite skoru DAS28 (disease activity score28)'in hesaplanması için serum C-reaktif protein (CRP) düzeyi $\mathrm{mg} / \mathrm{L}$ cinsinden saptandı ve hastadan genel sağlı̆̆ını 0 ile 10 arasında $(0=$ olabilecek en kötüden $10=$ olabilecek en iyi sağlık durumuna) puanlamas1 istendi. DAS28 değeri CRP ile DAS28 hesap makinesi ile hesapland. Daha sonra hastalardan sağlık değerlendirme anketini (HAQ) ve üst ekstremite fonksiyonel indeksi-15 (UEFI-15)'i doldurmaları istenmiştir. HAQ, günlük yaşam aktivitelerinin 20 soruyla sorgulandı $\breve{g}_{1}$ ve her sorunun " $0=$ rahatça yapıyorum; $1=$ biraz zorlanarak yapıyorum; 2= çok zor yapıyorum; $3=$ hiç yapamıyorum" şeklinde cevaplandığı toplam skoru 0 ile 60 arasında değişen bir anket olup; yüksek puan, yüksek engellilik düzeyini göstermektedir. UEFI-15 ise üst ekstremite fonksiyonlarını içeren 15 sorunun sorulduğu, soruların " $0=$ aşırı zor/yapamıyorum"dan "4= zorluk çekmiyorum" arasında puanlandığı, nihai skorun 0 ile 100 arasında değiştiği; düşük skorların daha fazla üst ekstremite fonksiyon bozukluğunu gösterdiği bir ankettir.

Sonrasında fiziyatrist tarafindan hastaların dominant üst ekstremitlerinden; başparmak interfalanjiyal (IP) ve metakarpofalanjiyal (MKF) eklem fleksiyonu, diğer tüm parmakların proksimal interfalanjiyal (PIP) ve $\mathrm{MKF}$ eklem fleksörlerinden, el bileği fleksör ve 


\section{Romatoid Artrit ve Kas Güçleri}

ekstansörlerinden, dirsek fleksör ve ekstansörleri ile omuzun fleksör, ekstansör, iç rotator (IR), dış rotator (ER), abduktör ve addüktör kaslarından kas güçleri manuel muscle tester (Lafayette instrument company, IN, USA) cihazı ile ölçüldü. Bu cihaz 10 saniyelik basışta uygulanabilen maksimum kuvvet ve 10 saniye boyunca uygulanabilen ortalama kuvveti kilogram cinsinden ölçebilen bir cihaz olup hastaların istenen hareketi 10 saniye boyunca uygulayabildikleri maksimum kuvvet ile uygulamaları istendi. Uygulayıcı, örnekle açıklamak amacıyla, ölçüm öncesi bir kez her hareketi kendi üzerinde tarif etti, hasta hareketi daha sonra uyguladı. Ölçümler yapılırken cihaza temas yüzeyi olarak parmaklarda parmak ucu, el bileği ölçümünde el ayası ve dorsal yüzü, dirsekte ön kol ortası, omuz hareketlerinden fleksiyon, ekstansiyon, abduksiyonda kol orta noktası kullanıldı. El bilek fleksiyon ve ekstansiyonu dirsek gövdeye bitişik 90 derece fleksiyonda, ön kol pronasyonda; dirsek fleksiyon ve ekstansiyonu omuz ve dirsek 90 derece fleksiyonda, ön kol supinasyonda ölçüldü. Omuz iç ve dış rotasyonları dirsek gövdeye bitişik ve 90 derece fleksiyon pozisyonunda, ön kol supinasyon - pronasyon orta noktasında, direnç noktası önkol orta yüzü olacak şekilde ölçüm yapıldı. Omuz abduksiyon ve adduksiyonu, omuz 90 derece abduksiyon pozisyonundan başlayacak şekilde dirsek ekstansiyonda ve önkol pronasyonda olacak şekilde ölçüldü. Hareketi değerlendirilen segmentin proksimalindeki segment, değerlendirici tarafindan stabilize edildi. Ölçümlerden bazı örnekler şekil 1 ve şekil 2'de gösterilmiştir. Direnç yüzeyi olarak parmaklarda parmak aparatı kullanılırken, yüzey uygunluğu açısından diğer ölçümlerde konveks geniş aparat kullanıldı. Hastaların baş parmak haricindeki diğer parmaklarının PIP ve MKF maksimum ve ortalama kas kuvvetleri toplanarak o ekstremite için toplam PIP ve MKF (PIP toplam, $\left.\mathrm{MKF}_{\text {toplam}}\right)$ değerleri elde edildi.

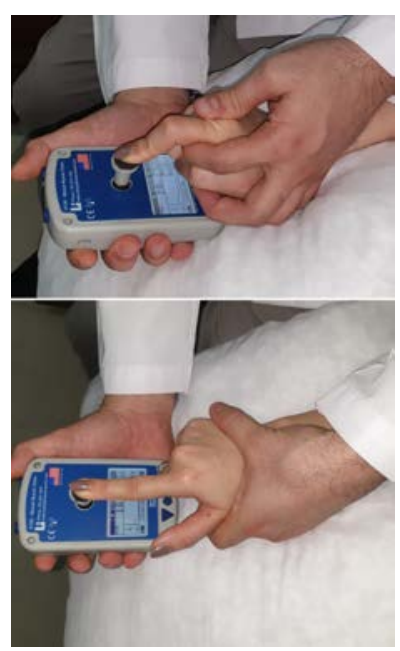

Şekil 1:

Ikinci proksimal interfalaniyal ve metakarpofalanjiyal eklem fleksörlerinin kas kuvvetlerinin ölçümü.

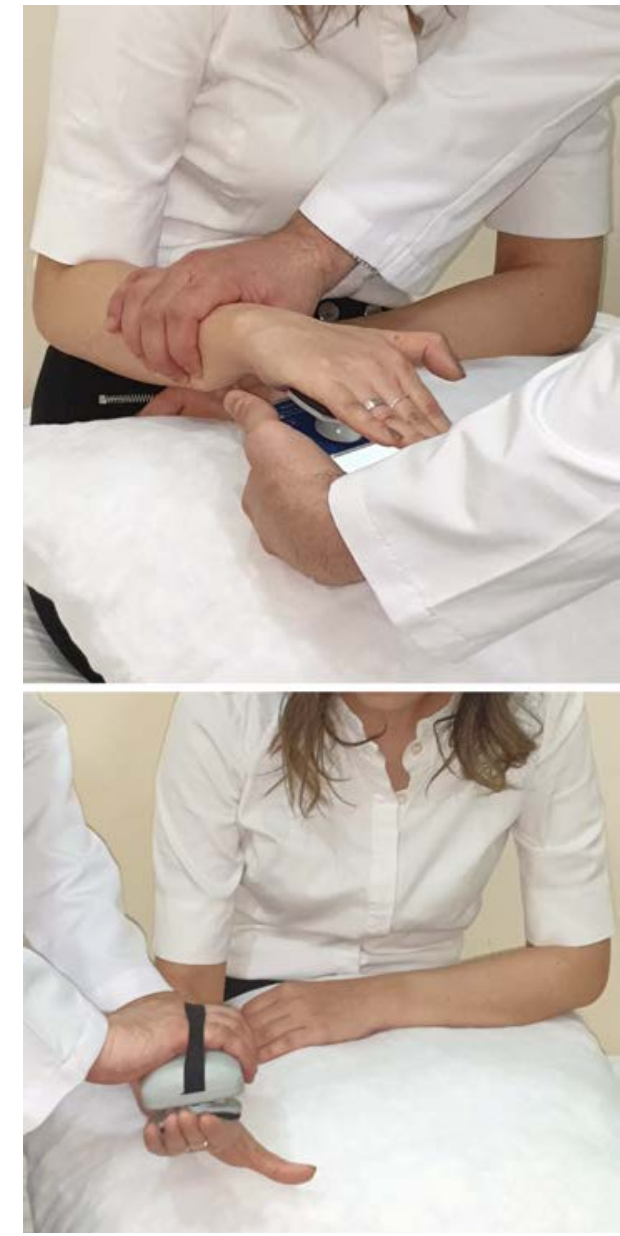

Şekil 2:

El bilek fleksör ve ekstnasör kas kuvvetlerinin ölçümü.

Toplam 20 gönüllü (10 hasta ve 10 kontrol) ile yapılan pilot çalışmadan elde edilen güç analizinde

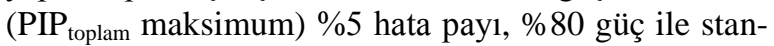
dart etki büyüklüğü 0.83 olacak şekilde her bir gruba 23 vaka alınması yeterli görülmüştür.

\section{İstatistiksel Analiz}

Verilerin istatistiksel analizi IBM Statistical Package for Social Sciences (SPSS) v23.0 istatistik paket programında yapılmıştır. Verinin normal dağılım gösterip göstermediği Shapiro-Wilk testi ile incelenmiştir. Verinin tanımlayıcı istatistikleri, sürekli verilerde normal dağılım gösteren değişkenler için (Ortalama \pm Standart Sapma), kategorik değişkenler için frekans ve yüzde [n (\%)] olarak belirtilmiştir. Normal dağılan sürekli veriler için bağımsız iki grubun karşılaştırılmasında "Bağımsız Örneklem t-Testi" (Independent Sample t-Test) kullanılmıştır. Kategorik verilerin analizinde "ki-kare" testi kullanılmıştır. Normal dağ1lan sürekli veride bağımsız iki değişken arasındaki ilişkiyi tespit etmek için "Pearson Korelasyon Katsayısı ile korelasyon analizi” kullanılmıştır. Anlamlılık düzeyi $\alpha=0.05$, güven aralığı $\% 95$ olarak belirlenmiştir. 


\section{Bulgular}

Çalışmaya 30 hasta, 30 sağlıklı kadın dahil edilmiş olup; hastaların yaş ortalaması $46.03 \pm 11.7$ yıl iken kontrol grubunun ise $47.2 \pm 16.8$ y1ldir. RA grubunda boy ortalamas1 $160.7 \pm 6.2 \mathrm{~cm}$, kilo ortalamas1 $76.17 \pm$ $12.6 \mathrm{~kg}$, vücut kitle indeksi (VKI) $29.71 \pm 5.9 \mathrm{~kg} / \mathrm{m}^{2}$ iken kontrol grubunda sirasiyla $162.5 \pm 5.5 \mathrm{~cm}, 63.3 \pm$ $12.2 \mathrm{~kg}$ ve $24.04 \pm 5.1 \mathrm{~kg} / \mathrm{m}^{2}$ idi. Hasta ve kontrol grubu arasında yaş, boy ve el dominansı açısından anlamlı fark bulunmazken, kilo ve VKİ hasta grubunda fazla bulunmuştur. Hasta grubunda 2 kişi (\%3.3) sadece nonsteroidal antiinflamatuar ilaçlar, 20 kişi (\%33.3) konvansiyonel sentetik hastal1k modifiye edici antiromatizmal ilaçlar (csDMARD), 5 kişi (\%8.3) biyolojik hastalık modifiye edici antiromatizmal ilaçlar (bDMARD), 3 kişi (\%5) hedefe spesifik hastalı modifiye edici antiromatizmal ilaçlar (tsDMARD) kullanıyordu. Hasta ve kontrol grubunun demografik verileri tablo I'de özetlenmiştir.

Tablo I. Hasta ve kontrol grubunun demografik verileri

\begin{tabular}{|l|c|c|c|}
\hline & $\begin{array}{c}\text { Hasta }(\mathrm{n}=30) \\
\text { ort } \pm \mathrm{SS} / \mathrm{n}(\%)\end{array}$ & $\begin{array}{c}\text { Kontrol }(\mathrm{n}=30) \\
\text { ort } \pm \mathrm{SS} / \mathrm{n}(\%)\end{array}$ & $\mathrm{p}$ \\
\hline Yaş (yıl) & $46.03 \pm 11.7$ & $47.2 \pm 16.8$ & $0.740^{\mathrm{t}}$ \\
\hline Kilo (kg) & $76.17 \pm 12.6$ & $63.3 \pm 12.2$ & $<0.00 \mathbf{t}^{\mathrm{t}}$ \\
\hline Boy (cm) & $160.7 \pm 6.2$ & $162.5 \pm 5.5$ & $0.240^{\mathrm{t}}$ \\
\hline VKi (kg/m²) & $29.71 \pm 5.9$ & $24.04 \pm 5.1$ & $<0.001^{\mathrm{t}}$ \\
\hline Dominans & & & \\
sağ $\quad \mathrm{n}(\%)$ & $27(90 \%)$ & $27(90 \%)$ & $1.000 \times^{2}$ \\
sol $\mathrm{n}(\%)$ & $3(10 \%)$ & $3(10 \%)$ & \\
\hline Hastalık süresi (ay) & $77.7 \pm 71.8$ & - & \\
\hline Illaç kullanımı & & - & \\
NSAil & $2(3.3 \%)$ & & \\
csDMARD & $20(33.3 \%)$ & & \\
bDMARD & $5(8.3 \%)$ & & \\
tsDMARD & $3(5 \%)$ & & \\
\hline
\end{tabular}

t: independent sample t-test, $\chi 2$ : ki kare testi, ort: ortalama, SS: standart sapma, VKİ: vücut kitle indeksi, NSAIII: nonsteroidal antiinflamatuar ilaçlar, DMARD: hastalık modifiye edici antiromatizmal ilaçlar, cs: konvansiyonel sentetik, b: biyolojik, ts: hedefe spesifik.

Hasta ve kontrol grubunun dominant ekstremite kas güçleri karşılaştırıldığında; RA grubunda hastaların başparmak IP ve MKF fleksiyon ile diğer parmakların toplam PIP ve MKF fleksiyon maksimum ve ortalama kas güçleri, kontrol grubundaki gönüllülerden anlamlı düşük bulunmuştur. RA grubunda el bileği fleksiyonunun maksimum ve ortalama değerleri, kontrol grubundan anlamlı düşük tespit edilirken; el bilek ekstansiyon güçleri arasında anlamlı fark tespit edilememiştir. Dirsek ekleminin fleksiyon ve ekstansiyon kas kuvvetleri her iki grupta benzer bulunmuştur. Omuz ekstansiyonu ortalama kas gücü, adduksiyon ve abduksiyon maksimum ve ortalama kas güçleri RA grubunda kontrol grubundan anlamlı düşük tespit edilir- ken; omuz iç rotasyonu maksimum ve ortalama değerleri RA grubunda kontrol grubundan anlamlı yüksek tespit edilmiştir. Değerlendirilen diğer kaslarda iki grup arasında anlamlı fark tespit edilememiştir. Kas güçlerinin iki grup arasında karşılaştırması Tablo II'de sunulmuştur.

Tablo II. Gruplar arası kas güçlerinin karşılaştırılması

\begin{tabular}{|l|c|c|c|}
\hline \multicolumn{1}{|c|}{ Kas Gücü } & $\begin{array}{c}\text { Hasta }(\mathrm{n}=30) \\
\text { ort } \pm \text { SS }\end{array}$ & $\begin{array}{c}\text { Kontrol } \\
\text { ort } \pm \text { SS }\end{array}$ & $P$ \\
\hline 1. IP fleks maks & $3.1 \pm 0.9$ & $4.2 \pm 1.4$ & $\mathbf{0 . 0 0 1}$ \\
\hline 1. IP fleks ort & $2.6 \pm 0.8$ & $3.4 \pm 1.2$ & $\mathbf{0 . 0 0 4}$ \\
\hline 1. MKF fleks maks & $3.1 \pm 1.1$ & $4.1 \pm 1.0$ & $<0.001$ \\
\hline 1. MKF fleks ort & $2.5 \pm 0.8$ & $3.4 \pm 1.0$ & $<0.001$ \\
\hline MKFtoplam fleks maks & $9.0 \pm 2.4$ & $11.3 \pm 3.2$ & $\mathbf{0 . 0 0 3}$ \\
\hline MKFtoplam fleks ort & $7.6 \pm 2.2$ & $9.1 \pm 2.3$ & $\mathbf{0 . 0 1 2}$ \\
\hline PIPtoplam fleks maks & $8.5 \pm 2.0$ & $10.6 \pm 3.1$ & $\mathbf{0 . 0 0 2}$ \\
\hline PIP Poplam fleks ort & $7.2 \pm 1.8$ & $8.7 \pm 2.5$ & $\mathbf{0 . 0 1 0}$ \\
\hline Bilek fleks maks & $7.3 \pm 1.6$ & $9.2 \pm 3.4$ & $\mathbf{0 . 0 1 1}$ \\
\hline Bilek fleks ort & $6.2 \pm 1.3$ & $7.4 \pm 2.8$ & $\mathbf{0 . 0 3 7}$ \\
\hline Bilek ekst maks & $6.8 \pm 1.4$ & $6.6 \pm 2.4$ & 0.691 \\
\hline Bilek ekst ort & $5.7 \pm 1.3$ & $5.4 \pm 1.9$ & 0.420 \\
\hline Dirsek fleks maks & $11.1 \pm 3.1$ & $10.0 \pm 2.2$ & 0.131 \\
\hline Dirsek fleks ort & $9.4 \pm 2.5$ & $8.3 \pm 1.8$ & 0.056 \\
\hline Dirsek ekst maks & $9.3 \pm 2.5$ & $10.6 \pm 3.3$ & 0.077 \\
\hline Dirsek ekst ort & $7.8 \pm 1.4$ & $8.6 \pm 2.7$ & 0.165 \\
\hline Omuz fleks maks & $8.9 \pm 1.8$ & $9.9 \pm 2.7$ & 0.128 \\
\hline Omuz fleks ort & $7.4 \pm 1.4$ & $8.1 \pm 2.1$ & 0.154 \\
\hline Omuz ekst maks & $8.1 \pm 2.2$ & $9.6 \pm 3.9$ & 0.075 \\
\hline Omuz ekst ort & $6.5 \pm 1.6$ & $7.9 \pm 2.8$ & $\mathbf{0 . 0 2 5}$ \\
\hline Omuz IR maks & $10.4 \pm 1.9$ & $9.0 \pm 3.6$ & $\mathbf{0 . 0 4 6}$ \\
\hline Omuz IR ort & $8.7 \pm 1.7$ & $7.4 \pm 2.4$ & $\mathbf{0 . 0 1 7}$ \\
\hline Omuz ER maks & $8.6 \pm 2.4$ & $8.7 \pm 2.4$ & 0.869 \\
\hline Omuz ER ort & $6.9 \pm 2.1$ & $7.3 \pm 1.9$ & 0.423 \\
\hline Omuz abd maks & $8.2 \pm 2.1$ & $10.6 \pm 3.3$ & $\mathbf{0 . 0 0 1}$ \\
\hline Omuz abd ort & $6.6 \pm 1.5$ & $8.6 \pm 2.5$ & $<0.001$ \\
\hline Omuz add maks & $10.1 \pm 2.6$ & $11.6 \pm 3.2$ & $\mathbf{0 . 0 4 3}$ \\
\hline Omuz add ort & $8.2 \pm 2.0$ & $9.5 \pm 2.4$ & $\mathbf{0 . 0 2 0}$ \\
\hline Üst ekstremite maks & $112.4 \pm 21.0$ & $126.0 \pm 27.0$ & $\mathbf{0 . 0 3 4}$ \\
\hline Üst ekstremite ort & $93.4 \pm 17.1$ & $103.1 \pm 20.1$ & $\mathbf{0 . 0 5 0}$ \\
\hline
\end{tabular}

İndependent sample t-test, ort: ortalama, SS: standart sapma, IP: interfalanjiyal, PIP: proksimal interfalanjiyal, MKF: metakarpofalanjiyal, fleks: fleksiyon, ext: ekstansiyon, maks: maksimum.

Hastaların hastalık aktivitesi ile kas güçleri arasındaki ilişki irdelendiğinde; DAS28 ile 1. IP fleksiyon maksimum ve ortalama değerleri, maksimum $\mathrm{MKF}_{\text {toplam }}$ fleksiyon ve ortalama $\mathrm{PIP}_{\text {toplam }}$ kas gücü arasında orta düzeyde negatif yönde anlamlı korelasyon elde edilmiştir. Ayrıca benzer şekilde el bilek fleksiyonu ortalama, el bilek ekstansiyonu maksimum ve ortalama, omuz fleksiyonu maksimum ve ortalama ile üst ekstremite toplam ortalama kas güçleri ile DAS28 arasında orta düzeyde negatif yönde anlamlı korelasyon tespit edilmiştir.

Hastaların UEFI-15 skorları ile kas güçlerinin ilişkisi incelendiğinde; el bilek ekstansiyon maksimum ve ortalama kas güçleri ile orta düzeyde pozitif yönde anlamlı korelasyon tespit edilmiştir. Ayrıca omuz 


\section{Romatoid Artrit ve Kas Güçleri}

fleksiyon, ekstansiyon, IR, adduksiyon ortalama kas güçleri ve omuz diş rotasyon maksimum kas güçleri ile UEFI-15 skorları arasında orta düzeyde pozitif yönde ilişki saptanmıştır. UEFI-15 skorları, üst ekstremite ortalama kas güçleri toplamı ile pozitif yönde anlamlı ilişki gösterirken üst ekstremite maksimum kas güçleri ile ilişkili bulunmamıştır.

Hastaların HAQ skorları ortalama el bilek fleksiyonu ve dirsek ekstansiyonu ile negatif ilişkili bulunmuştur. Omuzun ortalama ER ve maksimum adduksiyon kas güçleri dışındaki tüm kas kuvvetleri HAQ skorlarıyla anlamlı negatif ilişkili görünmektedir. Üst ekstremite kas güçleri maksimum ve ortalama kas güçleri toplamı, HAQ skorlarıyla negatif ilişkilidir. Kas güçleri, ölçekler ve hastalık aktivite skorları arasındaki ilişkiler Tablo III'te sunulmuştur.

Tablo III. Romatoid artrit hastalarında kas güçleri, ölçekler ve hastalık aktivite skoru arasındaki ilişki

\begin{tabular}{|c|c|c|c|}
\hline Kas Güçleri & UEFI-15 (r) & HAQ (r) & DAS28 (r) \\
\hline 1. IP fleks maks & 0.357 & -0.325 & $-0.499 * *$ \\
\hline 1. IP fleks ort & 0.283 & -0.299 & $-0.476^{* *}$ \\
\hline 1. MKF fleks maks & 0.176 & -0.168 & -0.304 \\
\hline 1. MKF fleks ort & 0.029 & -0.055 & -0.297 \\
\hline MKFtoplam fleks maks & 0.086 & -0.135 & $-0.371^{*}$ \\
\hline MKF Foplam fleks ort & 0.113 & -0.186 & -0.356 \\
\hline $\mathrm{PIP}_{\text {toplam }}$ fleks maks & 0.300 & -0.219 & -0.391 \\
\hline $\mathrm{PIP}_{\text {toplam }}$ fleks ort & 0.333 & -0.240 & $-0.410^{*}$ \\
\hline Bilek fleks maks & 0.227 & -0.323 & -0.321 \\
\hline Bilek fleks ort & 0.321 & $-0.366^{*}$ & $-0.380^{*}$ \\
\hline Bilek ekst maks & $0.476^{\star \star}$ & -0.238 & $-0.486^{\star \star}$ \\
\hline Bilek ekst ort & $0.495^{\star *}$ & -0.272 & $-0.492^{\star *}$ \\
\hline Dirsek fleks maks & -0.009 & -0.103 & -0.173 \\
\hline Dirsek fleks ort & 0.004 & -0.104 & -0.172 \\
\hline Dirsek ekst maks & 0.242 & -0.177 & -0.079 \\
\hline Dirsek ekst ort & 0.332 & $-0.437^{*}$ & -0.262 \\
\hline Omuz fleks maks & 0.338 & $-0.427^{*}$ & $-0.393^{*}$ \\
\hline Omuz fleks ort & $0.391^{*}$ & $-0.428^{*}$ & $-0.411^{*}$ \\
\hline Omuz ekst maks & 0.356 & $-0.400 *$ & -0.170 \\
\hline Omuz ekst ort & $0.401^{*}$ & $-0.445^{*}$ & -0.236 \\
\hline Omuz IR maks & 0.336 & $-0.515^{\star \star}$ & -0.198 \\
\hline Omuz IR ort & $0.394^{*}$ & $-0.589^{\star \star}$ & -0.285 \\
\hline Omuz ER maks & $0.417^{*}$ & $-0.418^{*}$ & -0.327 \\
\hline Omuz ER ort & 0.336 & -0.317 & -0.257 \\
\hline Omuz abd maks & 0.341 & $-0.443^{*}$ & -0.253 \\
\hline Omuz abd ort & 0.338 & $-0.392^{*}$ & -0.244 \\
\hline Omuz add maks & 0.311 & -0.358 & -0.118 \\
\hline Omuz add ort & $0.373^{*}$ & $-0.383^{*}$ & -0.123 \\
\hline Üst ekstremite maks & 0.353 & $-0.398^{*}$ & -0.357 \\
\hline Üst ekstremite ort & $0.380^{*}$ & $-0.424^{*}$ & $-0.393^{*}$ \\
\hline
\end{tabular}

Pearson korelasyon analizi ${ }^{*} \mathrm{p}<0,05{ }^{* *} \mathrm{p}<0,01$, IP: interfalanjiyal, PIP: proksimal interfalanjiyal, MKF: metakarpofalanjiyal, fleks: fleksiyon, ext: ekstansiyon, maks: maksimum, UEFI-15: üst ekstremite fonksiyonel indeksi-15, HAQ: sağlık değerlendirme anketi, DAS28: Hastalık aktivite skoru 28.

\section{Tartışma ve Sonuç}

Üst ekstremite ve fonksiyonları günlük yaşam aktivitelerinin çoğunda kullanıldığından tam bağımsızlık için önem arz etmektedir ${ }^{20}$. Uzun hastallk süresine sahip RA hastalarında sağlıklı insanlara göre kas kitlesi ve gücünde azalma, kas içi yağ kitlesinde artma olmaktadır $^{21}$. Bu nedenle romatoid artrit hastalarında el ve el bileği kasları genellikle etkilendiğinden bu kaslara yönelik egzersizler tedavinin bir parçası olarak görülmektedir ${ }^{10}$. Fakat üst ekstremitenin kalan kaslarında bu değişimin ne kadar olduğu ve günlük yaşam aktivitelerini nasıl etkilediği yeterince çalışılmamıştır. $\mathrm{Bu}$ alana 1şık tutan çalışmamızda, el ve el bileği kasları hastalık aktivitesinden en çok etkilenen kas grupları olarak tespit edilmiştir. Fakat el - el bileği kaslarından ziyade dirsek ekstansiyonu ve omuz kuşağı kaslarının ekstremite fonksiyonelliği ve engelliliği daha çok etkilediği görülmüştür. Üst ekstremite kaslarının toplam kuvveti hem hastalık aktivitesi hem de fonksiyonellik ve engellilik ile ilişkili bulunmuştur.

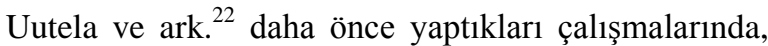
kavrama gücü, üst ve alt ekstremite endüransını (alt ekstremite çömelme, üst ekstremite alternatif dambıl itme hareketi ile), fiziksel aktiviteyi (Kasari frekans, yoğunluk, süre (FIT) testi ile) ve gövde endüransını (sit-up hareketi ile) ölçmüşler, ayrıca hastalara kısa form (SF)-36'nın fiziksel fonksiyon skorunu doldurtmuşlardır. Gövde, üst ve alt ekstremite kas gücü ve endüransının kombine edildiği kas performansı kompozit skorlarıyla DAS28 arasında negatif ilişki bulmuşlar ayrıca hastalığı remisyonda olanlarda FIT indeksi, SF-36 fiziksel fonksiyon alt skorlarında anlamlı yükseklik görmüşlerdir. Bizim çalışmamızda, tüm vücut performansından ziyade romatoid artritten daha fazla etkilenen üst ekstremite kas güçlerinin fonksiyonellik ve engellilik ile ilişkisi irdelenmiştir. Fakat bu çalışmayla benzer şekilde, üst ekstremite kas gücü ortalamalarının toplamının hastalık aktivitesi ile ilişkisi tespit edilmiştir. Hastalık aktivitesinin yüksekliği her ne kadar maksimum kas kuvvetlerinde azalmalar yapıyor olsa da bu ilişki orantısal olmayıp aktivite artışı maksimum kuvvetten ziyade ortalama üst ekstremite kas kuvvetlerini etkilemektedir. Aynı şekilde, üst ekstremite fonksiyonelliği de maksimum kuvvetten ziyade ortalama kas kuvvetleri ile ilișkili bulunmuştur. Engellilik ile hem maksimum hem ortalama kas kuvvetlerinin ilişkisi tespit edilirken ilişki ortalama kas kuvvetlerinde istatistiksel olarak daha kuvvetli görünmektedir. Bu hasta grubunda, kas endüransını arttırmak, maksimum kas kuvvetlerini arttırmaktan daha akılcı görünmektedir.

Parmak ucu, anahtar ve palmar tutma hareketleri ile kavrama hareket gücünün üst ekstremite engelliliğini gösteren "the disabilities of the arm shoulder and hand (DASH)" ve el fonksiyonlarını gösteren "Michigan el 


\section{O.V. Yurdakul, ark.}

çıktısı anketi (MHQ)" ve DAS28 ile ilişkisini araştırdıkları çalışmalarında Romero-Guzmán ve ark. ${ }^{23}$, hastalık aktivitesi yüksek romatoid artrit hastalarında kontrol hastalarına göre tüm parametrelerde kötüleşme tespit etmişlerdir. Remisyondaki hastalarda ise DASH ve anahtar tutma gücü kontrol ile ayniyken; MHQ, parmak ucu ve palmar tutma hareketlerini RA hastalarında kontrollere göre kötü bulmuşlardır. Bizim çalışmamıza benzer şekilde, DAS28'i el fonksiyonlarındaki bozulma ile ilişkili bulmuşlar fakat üst ekstremite fonksiyonları ile ilişkiyi çalışmamışlardır. Bir yıllık takipte DAS28 ile el fonksiyonlarındaki değişim ilişkili tespit etmişler. Bizim çalışmamızda; kitlesel fonksiyonel hareketler olan tutma ve kavrama kuvvetleri yerine el kas gruplarının spesifik olarak incelenmesi tercih edilmiştir. Bu nedenle el kas kuvvetleri MKF ve PIF eklemler ayrı olacak şekilde ölçüldü. İşlevlerinin diğer parmaklardan farklı olması nedeniyle, başparmak diğer parmaklardan ayrı değerlendirildi. El kas kuvvetlerinin tamamı ve el bileğinde sadece fleksiyon kas kuvveti kontrol grubuna göre anlamlı derecede azalmıştı, fakat el bilek ekstansiyon kas kuvveti hasta grubunda kontrol grubu ile benzerdi. El bilek ekstansörleri hastalık aktivitesi ile ilişkili bulundu. Yani el bilek ekstansörleri her ne kadar normal değerlerin altına düşmese de hastalık aktivitesinden etkilenmektedir. Enteresan bir şekilde, omuz iç rotasyonu maksimum ve ortalama değerleri RA grubunda hasta grubundan anlamlı yüksek tespit edilmiştir. $\mathrm{Bu}$ durum zayıf kas kuvvetlerinin telafisi yönünde bazı kas kuvvetlerinde artış olabileceğini düşündürmektedir.

Stucki ve ark. ${ }^{24}$ omuz, dirsek, el bileği, kalça, diz ve ayak bileği kaslarından askı terazisi ile yaptıkları ölçümlerin ortalaması ile bir kas kuvveti indeksi elde etmişler ve bu indeksin hastalık aktivitesi ile ilişkili olduğunu saptamışlardır. Fakat çalışmalarına fonksiyonellikte önemli rolleri olan omuzun iç ve diş rotasyonlarını dahil etmemişler ve ayrı ayrı kas güçlerinin hastalık aktivitesi ile ilişkisini araştırmamışlardır. Ayrıca analizlerini sadece kas gücüne yoğunlaştırmış, fonksiyonellik ve engelliliği göz ard1 etmişlerdir. Çalışmamızda hastalık aktivitesi el- el bileği ve omuz eklemleri ile ilişkiliyken; fonksiyonelliği, dirsek ekstansiyon ve omuz kuşağı kas kuvvetlerinin etkilediği saptanmıştır. $\mathrm{Bu}$ nedenle bu hasta grubunda birleşik kas gruplarıyla değerlendirmeler yapmak yerine kas gruplarını ayrı ayrı değerlendirmek mantıklı görünmektedir.

RA hastalarında azalmış el fonksiyonları sıklıkla görülmekte olup bu durumun ağrı inhibisyonu, inaktivite, psikolojik faktörler, miyopati ve deformitelere bağl1 oluştuğu düşünülmektedir ${ }^{25,26}$. Petchiappan ve ark. ${ }^{27}$ RA ve fibromiyalji hastalarında el kavrama kuvvetlerini araştırmışlar, RA hastalarında el kavrama kuvvetini fibromiyalji hastalarından daha düşük bulmuşlar ayrica hem RA hem fibromiyalji hastalarının el kavrama kuvvetlerini normal popülasyondan düşük tespit etmişlerdir. Bodur ve ark. $^{28}$ el engelliliği ve eklem hasarı ile çeşitli demografik, klinik ve laboratuvar parametrelerinin ilişkisini araştırmışlar; tutma ve kavramayı el engelliliği ve eklem hasarıla en ilişkili parametreler olarak saptanmışlardır. Fakat bu çalışmada kas kuvvetlerinden sadece kavrama ve tutma güçlerine bakılmış ve üst ekstremiteden ziyade sadece el fonksiyonları göz önüne alınmıştır. Çalışmamız 1şığında, bu hasta grubunda engellilik ve fonksiyonelliğin sadece el ile değerlendirilemeyeceği gösterilmiştir.

Dedeoğlu ve ark. ${ }^{17}$ bizim çalışmamızdan farklı olarak elle kavrama ve tutma güçlerini DAS28 dişında, HAQ ve fonksiyonel bozukluk sinyalleri (SOFI) indeksi ile ilişkili bulmuşlardır. SOFI indeksi üst ve alt ekstremite fonksiyonelliğini bir arada değerlendiren bir indeks olduğundan biz çalışmamızda sadece üst ekstremite fonksiyonlarını değerlendiren UEFI-15 skalasını kullanmayı uygun gördük. Ayrıca; dirsek ve omuz hareketlerinin fonksiyonelliğe katkısını da saptamaya çalıştık. Normal değerleri saptamak için kontrol grubunu çalışmamıza dahil ettik. Bu çalışma ile bizim çalışmamız arasındaki fark metodolojik farklılıklardan kaynaklanıyor olabilir.

İlgi çekici bir başka nokta ise romatoid artritli hastalarda VKI'nin kontrol hastalarına göre yüksek bulunmuş olmasıdır. Bizim çalışmamıza benzer şekilde Albrecht ve ark. ${ }^{29}$ Alman popülasyona ait 3 büyük kohortu incelemişler ve inceledikleri tüm kohortlarda RA'lı hastalarda VKİyi genel popülasyondan fazla tespit etmişlerdir. Bu durumun romatoid artritli hastalarda eklem tutulumuna bağlı olarak fonksiyonel kapasitede azalma ve hareket azlığı ile ilişkili olabileceğini düşünmüşlerdir. Benzer şekilde Feng ve ark. ${ }^{30}$ yaptıkları meta-analizde yüksek VKİ ile RA arasında ilişki bulmuşlar, VKİ yüksek hastaların RA gelişimine yatkın oldukları sonucuna varmışlardır. Adipöz doku ile immünojenisite arasındaki ilişki son yıllarda ilgi çekmekte olup, bu bulgular hastaların el kaslarını kuvvetlendirici egzersizler dışında kilo kontrolü sağlayan ve büyük kas gruplarının güçlerini arttıran egzersizlere teşvik edilmesi gerektiğini düşündürmektedir.

Çalışmamızın birtakım kısıtlılıkları bulunmaktadır. Öncelikle çalışmamızdaki görece düşük örneklem sayısı sonuçları etkiliyor olabilir. Ayrıca çalışmamızda üst ekstremite kas güçlerinden parmak ekstansörleri ve el bileği ulnar ve radial deviasyonları ölçümdeki teknik zorluk ve günlük yaşam aktivitelerine etkilerinin kısıtlı olması nedeniyle değerlendirilememiştir. Ayrıca kas kuvvetinde homojenliği sağlamak adına sadece kadın cinsiyet çalışmaya alınmış olup erkek popülasyon değerlendirme dışı bırakılmıştır. Bir başka kısıtlılık ise kullanılan farklı ilaçların kas gücü değerlendirmesi üzerine etkisinin araştırılmamış olmasıdır. Antiromatizmal ilaçların kas gücü üzerine direkt etkisi literatürde aydınlatılmamıştır. Fakat ilaç kullanımının 


\section{Romatoid Artrit ve Kas Güçleri}

hastalık aktivitesini kontrol altına alarak romatoid kaşeksiyi düzeltmesi ve dolaylı yoldan kas gücünü arttırması beklenebilir.

Romatoid artrit hastalığında medikal tedavi seçenekleri ciddi oranda artmış olmasına rağmen hastaların birçoğu halen vücut fonksiyon kayıplarından şikayet etmektedir. Bunun önüne geçebilmek ancak medikal tedavi ve egzersiz programlarının bir arada uygulanmasıyla mümkün görünmektedir. Literatürdeki çalışmalar hastalık tutulumunun el eklemlerinde daha fazla olmasının etkisiyle genellikle el ve el bileği kas kuvvetlerinin değerlendirilmesine yoğunlașmıștır. Diğer kas gruplarının hastalık aktivitesinden nasıl etkilendiği ile ilgili net veriler olmadığından biz bu çalışmada, kadın RA hastalarının dominant üst ekstremitelerinde hastalık aktivitesi ile etkilenen kas gruplarını tespit etmeyi, bu kas gruplarının üst ekstremite fonksiyonellik ve engellilik ile ilişkisini saptamayı amaçladık. Bu çalışmamızda hastalık aktivitesi ile bu kas grupları ilişkili olmasına rağmen, fonksiyonellik ve engelliliğin bu kas gruplarından ziyade üst ekstremitenin daha büyük ve güçlü kas gruplarıyla ilişkili olduğu tespit edilmiştir. Eklem tutulumu ile kas tutulumunun birbirinden farklı tutulum şekilleri olduğu göz önüne alınmalı, hastalarda fonksiyonellik kazanımları ve engellilikte azalma sağlanması isteniyorsa egzersiz programlarında el ile ilişkisiz kasların güçleri de göz önüne alınmalıdır. Bu konuda daha fazla çalışma yapılmasıyla beraber en uygun egzersiz programlarına ulaşılabilecektir.

\section{Kaynaklar}

1. Choy E. Understanding the dynamics: pathways involved in the pathogenesis of rheumatoid arthritis. Rheumatology (Oxford). 2012;51 Suppl 5:v3-11.

2. Alamanos Y, Drosos AA. Epidemiology of adult rheumatoid arthritis. Autoimmun Rev. 2005;4(3):130-136.

3. Beenakker KG, Ling CH, Meskers CG, et al. Patterns of muscle strength loss with age in the general population and patients with a chronic inflammatory state. Ageing Res Rev. 2010;9(4):431-436.

4. Summers GD, Metsios GS, Stavropoulos-Kalinoglou A, Kitas GD. Rheumatoid cachexia and cardiovascular disease. Nat Rev Rheumatol. 2010;6(8):445-451.

5. Schaap LA, Pluijm SM, Deeg DJ, et al. Higher inflammatory marker levels in older persons: associations with 5-year change in muscle mass and muscle strength. J Gerontol A Biol Sci Med Sci. 2009;64(11):1183-1189.

6. Cooney JK, Law RJ, Matschke V, et al. Benefits of Exercise in Rheumatoid Arthritis. J Aging Res. 2011;2011.

7. Biolo G, Cederholm T, Muscaritoli M. Muscle contractile and metabolic dysfunction is a common feature of sarcopenia of aging and chronic diseases: from sarcopenic obesity to cachexia. Clin Nutr. 2014;33(5):737-748.

8. Madenci E, Gursoy S. Hand deformity in rheumatoid arthritis and its impact on the quality of life. The pain clinic. 2003;15(3):255-259.

9. Hakkinen A, Sokka T, Kotaniemi A, et al. Muscle strength characteristics and central bone mineral density in women with recent onset rheumatoid arthritis compared with healthy controls. Scand J Rheumatol. 1999;28(3):145-151.

10. Walker JM, Helewa A. Physical rehabilitation in arthritis. 2nd ed. St. Louis: Elsevier; 2004.

11. Wozny W, Long C, 2nd. Electromyographic kinesiology of the rheumatoid hand. Arch Phys Med Rehabil. 1966;47(11):699704.

12. Van den Ende CH, Vliet Vlieland TP, Munneke M, Hazes JM. Dynamic exercise therapy in rheumatoid arthritis: a systematic review. Br J Rheumatol. 1998;37(6):677-687.

13. de Jong Z, Vliet Vlieland TP. Safety of exercise in patients with rheumatoid arthritis. Curr Opin Rheumatol. 2005;17(2):177182.

14. Guidelines ACoRSoRA. Guidelines for the management of rheumatoid arthritis: 2002 update. Arthritis Rheumatism. 2002;46(2):328-346.

15. Singh JA, Saag KG, Bridges Jr SL, et al. 2015 American College of Rheumatology guideline for the treatment of rheumatoid arthritis. Arthritis rheumatology. 2016;68(1):1-26.

16. Combe B, Landewe R, Daien CI, et al. 2016 update of the EULAR recommendations for the management of early arthritis. Ann Rheum Dis. 2017;76(6):948-959.

17. Dedeoglu M, Gafuroglu U, Yilmaz O, Bodur H. The relationship between hand grip and pinch strengths and disease activity, articular damage, pain, and disability in patients with rheumatoid arthritis: romatoid artritli hastalarda elle kavrama ve tutma guclerinin hastalik aktivitesi, eklem hasari, Agri ve engellilik ile Iliskisi. Turkish journal of rheumatology. 2013;28(2):69-78.

18. Dogu B, Sirzai H, Yilmaz F, Polat B, Kuran B. Effects of isotonic and isometric hand exercises on pain, hand functions, dexterity and quality of life in women with rheumatoid arthritis. Rheumatol Int. 2013;33(10):2625-2630.

19. Bodur H, Yilmaz Ö, Keskin D. Hand disability and related variables in patients with rheumatoid arthritis. Rheumatol Int. 2006;26(6):541-544.

20. Eberhardt K, Sandqvist G, Geborek P. Hand function tests are important and sensitive tools for assessment of treatment response in patients with rheumatoid arthritis. Scand $J$ Rheumatol. 2008;37(2):109-112.

21. Baker JF, Von Feldt J, Mostoufi-Moab S, et al. Deficits in muscle mass, muscle density, and modified associations with fat in rheumatoid arthritis. Arthritis Care Res (Hoboken). 2014;66(11):1612-1618.

22. Uutela TI, Kautiainen HJ, Häkkinen AH. Decreasing muscle performance associated with increasing disease activity in patients with rheumatoid arthritis. PLoS One. 2018;13(4):e0194917.

23. Romero-Guzmán AK, Menchaca-Tapia VM, Contreras-Yáñez I, Pascual-Ramos V. Patient and physician perspectives of hand function in a cohort of rheumatoid arthritis patients: the impact of disease activity. BMC Musculoskelet Disord. 2016;17:392.

24. Stucki G, Schonbachler J, Bruhlmann P, Mariacher S, Stoll T, Michel BA. Does a muscle strength index provide complementary information to traditional disease activity variables in patients with rheumatoid arthritis? J Rheumatol. 1994;21(12):2200-2205.

25. Ekblom B, Lovgren O, Alderin M, Fridstrom M, Satterstrom G. Physical performance in patients with rheumatoid arthritis. Scand J Rheumatol. 1974;3(3):121-125.

26. Tiselius P. Studies on joint temperature, joint stiffness and muscle weakness in rheumatoid arthritis. An experimental and clinical investigation. Acta Rheumatol Scand. 1969;14:Suppl $14: 11+$.

27. Petchiappan V, Selvam S, Dhanush M, Prabu N. Assessment of Handgrip Strength in Patients with Rheumatoid Arthritis and 


\section{O.V. Yurdakul, ark.}

Fibromyalgia - Do They Differ? An Observational Study. Archives of Medicine. 2018;10(4:3):1-5.

28. Bodur H, Yilmaz O, Keskin D. Hand disability and related variables in patients with rheumatoid arthritis. Rheumatol Int. 2006;26(6):541-544.

29. Albrecht K, Richter A, Callhoff J, et al. Body mass index distribution in rheumatoid arthritis: a collaborative analysis from three large German rheumatoid arthritis databases. Arthritis Res Ther. 2016;18:149.

30. Feng J, Chen Q, Yu F, et al. Body Mass Index and Risk of Rheumatoid Arthritis: A Meta-Analysis of Observational Studies. Medicine (Baltimore). 2016;95(8):e2859. 